UDK 614.7

\title{
METHODOLOGICAL APPROACHES TO THE DEVELOPMENT OR HYGIENIC STANDARDS USING HEALTH RISK CRITERIA AND THEIR APPLICATION IN THE CASE OF AMBIENT AIR MANGANESE
}

\author{
N.V. Zaitseva', P.Z. Shur ${ }^{1}$, M.A. Zemlyanova ${ }^{1}$, N.G. Atiskova' ${ }^{1}$, A.A. Khasanova ${ }^{2}$, \\ K.V. Romanenko ${ }^{2}$, V.A. Fokin ${ }^{2}$, D.L. Masunina ${ }^{2}$ \\ ${ }^{1}$ FBSI "Federal Scientific Center for Medical and Preventive \\ Health Risk Management Technologies", \\ 82, Monastyrskaya St., Perm, 614045, Russia, \\ ${ }_{2}^{2}$ Perm State University, 15, Bukireva St., Perm, 614990, Russia
}

\begin{abstract}
Results of ambient air manganese hygienic standard development using health risk assessment approaches harmonized with international ones are presented. According to health risk level evolutionary modeling results as annual average ambient air manganese standard $0.00005 \mathrm{mg} / \mathrm{m}^{3}$ was offered, as relevant critical effects - hypersensitivity reactions.
\end{abstract}

Key words: health risk assessment, evolutionary modelling, manganese, benchmark level.

The Russian Federation's participation in the WTO and the Customs Union within the Eurasian economic community makes optimizing the sanitary law, particularly, bringing the sanitary-hygienic standards of the environmental quality in accordance with the international standards, one of the top priorities.

Risk assessment today is the key element in setting up the environmental safety standards. It must be conducted based on a structured approach that includes hazard identification, exposition assessment, dose-response relationship evaluation and risk analysis [6, $8,13]$.

According to Canadian Environmental Quality Guidance, Canadian Council of Ministers of the Environment [8], the air quality standards are developed based on the following principles: the standards set for air pollutants shall not create public hazard; the standards shall be developed

(c) Zaitseva N.V., Shur P.Z., Zemlyanova M.A., Atiskova N.G., Khasanova A.A., Romanenko K.V., Fokin V.A., Mazunina D.L., 2014

Zaitseva Nina Vladimirovna - member of the Russian Academy of Medical Sciences, Doctro of Medical Sciences, Professor, Director (e-mail: znv@fcrisk.ru; phone: +7 (342) 237-25-34). 37).

Shur Pavel Zalmanovich - Doctro of Medical Sciences, Academic Secretary (e-mail: shur@fcrisk.ru; phone: +7 (342) 238-33-

Zemlyanova Marina Aleksandrovna - Doctor of Medical Sciences, Head of Biochemical and Cytogenetic Diagnostics Laboratory (e-mail: zem@fcrisk.ru; phone: +7 (342) 236-39-30).

Atiskova Nina Georgievna - leading risk assessment specialist, Public Risk Analysis Sector (e-mail: atiskova@fcrisk.ru; phone: +7 (342) 238-33-37).

Khasanova Anna Alekseyevna - risk assessment specialist, Public Risk Analysis Sector (e-mail: sharaeva@fcrisk.ru; phone: +7 (342) 238-33-37).

Romanenko Kristina Vladimirovna - risk assessment specialist, Public Risk Analysis Sector (e-mail: romanenko@fcrisk.ru; phone: +7 (342) 238-33-37).

Fokin Vladimir Andreyevich - risk assessment specialist, Public Risk Analysis Sector (e-mail: fokin@fcrisk.ru; phone: +7 (342) 238-33-37).

Mazunina Daria Leonidovna - research assistant, Biochemical and Cytogenetic Diagnostics Sector (e-mail: mix.darja@yandex.ru; phone: +7 (342) 236-39-30). 
Scientific and methodological approaches to risk analysis

for a believable exposure scenario; a critical effect for health shall be determined with the account for the most sensitive population groups; the standards shall be credible and feasible.

In the Russian Federation, the maximal one-time and daily average maximum permissible concentrations are used as they hygienic standards for the pollutants in the air. Those standards do not fully represent the inhalation effects from the chemicals throughout one's life and thus may not be used for the purposes of health risk assessment which in its turn requires the use of the quantities that take into account the safety of life-long exposure. Specific standards for the Russian Federation that may be used in risk assessment can be obtained after setting-up riskbased standards with annual averaging.

In accordance with an internationally acknowledged risk assessment methodology at the state of hazard identification with the use of a set of criteria, a priority pollutant is selected which is later used to determine a risk-based standard for the air pollutant concentrations. The developed criteria for the determination of the priority air pollutants under chronic inhalation exposure include the differences between the standard values in the Russian Federation and in other countries; the data about the toxic and hazard levels of chemical components including cancer potential; being included in the international and national lists of priority pollutants; the data about the abundance in the environment [7].

At the stage of exposure assessment, the agent enters the body with the air in a determined quantity in real-life conditions $[6,13]$. The next stage of the risk assessment procedure is evaluation of the 'exposure-response relationship which includes empirical determination of the relationship between the exposure of the chemical under study and organ/system dysfunction, with the account for its intensity [6, 13].

When assessing non-cancer health risks under chemical exposure, it is possible to use various paired-comparison mathematical models included in the guidelines and recommendations of the leading international organizations (WHO, OECD, etc.) or in the published research papers (EPA, ATSDR etc.). If no 'exposure-response' model is available, it is possible to use the results of specialized epidemiological studies.

When modelling 'exposure-response' relationships for non-cancer risk assessment purposes, a liminality principle is used according to which negative health effects are displayed starting from the reference level. In the course of the study, we had several hypotheses about the relationship between the exposition of different levels and the development of health disorders; at that, the population group under the exposure below the level under study was considered the control group, and above the level under study - the experimental group. For each of the hypotheses, we tested the relationship in terms of odd ratio; its value served as a basis for the 
Scientific and methodological approaches to risk analysis

mathematical relationship model of the 'chemical concentration in the air - odd ratio'. For the reference level of the air pollutant, we used a value that corresponded with the $95 \%$ confidence limit of the built model.

Additionally, in order to evaluate the 'exposure-response' relationship, it is also possible to use multiple evolutionary models that reflect the impact of chemicals on the incidence of health disorders depending on the age and length of exposure and taking into account the accumulation of functional disorders due to natural causes. Determination of the risk-based standard value for the air chemical is conducted based on the reference level and the uncertainty factor (UF). The value of the uncertainty factor is determined with the account for a possible impact on the reliability of evaluation of a number of factors. When selecting the values of the uncertainty factor components, the following is recommended to be accounted for: intraspecific extrapolation; propagation of the data obtained in the conditions of relatively short-term exposure to longer exposure; effect on the growing organism; extrapolation from one route of entry to another, transfer from a minimum database to a full database, etc. [5, 13].

At the stage of risk description, we conducted the assessment of risk acceptability to health using the atmospheric air quality standards. When developing risk-based atmospheric air quality standards in the Russian Federation in accordance with the internationally approved risk assessment procedure at the stage of hazard identification based on the ab chemical ove selection criteria, manganese was included in the list of priority chemicals for the risk-based air quality standardization.

The choice of manganese for the development of risk-based standards is explained by significant differences in the values of manganese regulation for the atmospheric air under chronic exposure in the Russian Federation and abroad. Analysis of the current hygienic standards of the air levels of manganese used in Russia and abroad showed the differences both in the methodology of their determination and the values of those indicators. For example, the Agency for Toxic Substances and Disease Registry (ATSDR) recommends that the MRL of manganese (Minimal Risk Level) equal - $0.00004 \mathrm{mg} / \mathrm{m} 3[14]$.

According to the WHO (1999) [9], the recommended air level of manganese is 0.00015 $\mathrm{mg} / \mathrm{m} 3$. Additionally, a group of researchers including M. Egyed and G.C. Wood (1996) [11] recommend that the normative air level of manganese equal $0.0001 \mathrm{mg} / \mathrm{m} 3$. The U.S. Environmental Protection Agency sets the recommended air level of manganese and its compounds at $0.00005 \mathrm{mg} / \mathrm{m} 3$ [10]. As for REL (Reference Exposure Level), the Office of Environmental Health Hazard Assessment recommends that the value equal $0.0002 \mathrm{mg} / \mathrm{m} 3$. 
Scientific and methodological approaches to risk analysis

According to GN 2.1.6.1338-03 [1], the value of Threshold Allowable Concentration TACcc, set for the developed effects, manganese and its compounds in the RF, equal $0.001 \mathrm{mg} / \mathrm{m} 3$.

Additionally, manganese is included in the International ATSDR list of hazardous substances and the sampling plan within the socio-hygienic monitoring system of a number of the RF subjects. To assess exposure, we used the estimated data on air pollution in an industrial town in the points of residence of each child approximated based on the results of instrumental research [2]. The range of levels of manganese in ambient air in the area of residence of the group under study totaled from 0.000014 to $0.00022 \mathrm{mg} / \mathrm{m} 3$.

The reference levels of manganese in ambient air were determined based on a crosssectional epidemiological study that included 382 children aged 3-7 residing in an industrial town. The level of health in that group was assessed based on a multi-year data on medical referrals.

We reviewed nosological activities as responses when modelling the 'manganese level in ambient air - chance ratio' relationship, including representatives of the three classes of diseases by MKB-10 (V - mental and behavioral disorders; VI - diseases of the nervous system; X diseases of the respiratory system), corresponding to the critical organs and systems for the conditions of chronic inhalation exposure to manganese [6]. Moreover, since manganese is a proved allergy-causing agent, we took into account the respective health effects, including nosological, when modelling the 'manganese level in ambient air - chance ratio' relationship $[12,14]$.

In the process of mathematical modelling, we developed and evaluated 29 models of 'manganese level in the ambient air - chance ratio' relationships. As most appropriate for the objectives of the study, the following models and values of the reference levels were selected: for sleep disorders (G 47) - $0.00009 \mathrm{mg} / \mathrm{m} 3$; atopic dermatitis (L 28.0) - 0,00008 mg/m3; increase in the absolute number of eosinocytes $-0,0002 \mathrm{mg} / \mathrm{m} 3$, increase in the number of general $\operatorname{IgE}-0,00004 \mathrm{mg} / \mathrm{m} 3$. By criteria of the limiting indicator, the reference level of manganese in ambient air may be equal $0.00004 \mathrm{mg} / \mathrm{m} 3$.

However, uncertainties related to the presence in the ambient air (in the area under study) of a number of pollutants that have synergetic effect with manganese have a considerable impact in the reliability of results of epidemiological studies used to determine the reference levels. In order to minimize the uncertainties when determining the values of risk-based standards of the levels of manganese in ambient air, we created a risk evolution model, which is considered one of the most adequate methods used to predict and assess potential environmental impact on public health [3]. 
Scientific and methodological approaches to risk analysis

Within this study, the health risk evolution model was built with the use of a linear nonthreshold model, calculation of a coefficient that reflects the impact of the factors on the intensity of risk accumulation, and determination of the levels of manganese in ambient air corresponding to the risk magnitude below 0.05 which is considered small to negligible (acceptable, permissible), not different from the regular everyday risk [4].

Based on the results of the mathematical modelling of risk evolution for atopic dermatitis as a specific response for manganese in the conditions of chronic inhalation exposure, the level at which the health risk is small to negligible totaled $0.00005 \mathrm{mg} / \mathrm{m} 3$. The level of 0.00005 $\mathrm{mg} / \mathrm{m} 3$ for manganese in ambient air may be considered inactive and used for the subsequent determination of risk-based standard of the ambient air quality. Calculation of the final value of risk-based standard of ambient air quality for manganese is conducted with the use of the inactive level determined on the basis of evolutionary modelling and cumulative uncertainty coefficient [5].

For this type of study, we reviewed the following uncertainty factors:

- uncertainty factor that accounts for the cross-species extrapolation - 1 , as we used an inactive level obtained in the result of the epidemiological study;

- uncertainty factor that accounts for the intraspecific extrapolation - 1, as we studied the impact on a sensitive group (children aged 3-7);

- uncertainty factor associated with the transition of the study results from the high levels of exposure to the low levels - 1, as the study was conducted in the conditions of real-time exposure.

Consequently, the value of the quality standard of ambient air determined on the basis of the health risk assessment totals $0.00005 \mathrm{mg} / \mathrm{m} 3$; the critical effect for manganese - allergic reactions. The obtained results correspond with the ones of the US EPA.

Therefore, the principle activities aimed at bringing together the sanitary-hygienic standards of environmental quality in the RF with the international standards include the development of risk-based standards that take into account the annual averaging period with the use of epidemiological research methods.

These new approaches were tested when determining the risk-based standards of the level of manganese in ambient air. The approaches will be widely used to improve the hygienic standards in the Russian Federation. 


\section{References}

1. GN 2.1.6.1338-03. Predel'no dopustimye kontsentratsii (PDK) zagryaznyayushchikh veshchestv $\mathrm{V}$ atmosfernom vozdukhe naselennykh mest [GN 2.1.6.1338-03. Maximum permissible concentration (MPC) of pollutants in the air of residential areas].

2. May I.V., Vekovshinina S.A., Chigvintsev V.M. Sopryazhenie dannykh instrumental'noy i raschetnoy otsenki kachestva atmosfernogo vozdukha g. Permi dlya zadach ekologo-gigienicheskogo zonirovaniya territorii [Connection of the data of instrumental and calculated Perm City air quality assessment for the tasks of ecological and hygienic territory zoning]. Vestnik Permskogo universiteta Seriya Biologiya, 2010, no. 2, pp. 60-64.

3. Zaytseva N.V., Trusov P.V., Shur P.Z., Kir'yanov D.A., Chigvintsev V.M., Tsinker M.Yu. Metodicheskie podkhody $\mathrm{k}$ otsenke riska vozdeystviya raznorodnykh faktorov sredy obitaniya na zdorov'e naseleniya na osnove evolyutsionnykh modeley [Methodological approaches to assessing the risk of exposure of diverse environmental factors on human health based on evolutionary models]. Analiz riska zdorov'yu 2012, no. 1, pp. 15-22.

4. MR 2.1.10.0062-12 «Kolichestvennaya otsenka nekantserogennogo riska pri vozdeystvii khimicheskikh veshchestv na osnove postroeniya evolyutsionnykh modeley» [MR 12 2.1.10.0062. Quantifying non-cancer risk from exposure to chemicals based on constructing evolutionary models].

5. Onishchenko G.G., Novikov S.M., Rakhmanin Yu.A., Avaliani S.L., Bushtueva K.A. Osnovy otsenki riska dlya zdorov'ya naseleniya pri vozdeystvii khimicheskikh veshchestv, zagryaznyayushchikh okruzhayushchuyu sredu [Fundamentals of assessing public health risk from exposure to chemicals polluting the environment]. Ed. by Rakhmanin Yu.A., Onishchenko G.G. Moscow: NII ECh i GOS, 2002. 408 p.

6. R.2.1.10.1920-04. Rukovodstvo po otsenke riska dlya zdorov'ya naseleniya pri vozdeystvii khimicheskikh veshchestv, zagryaznyayushchikh okruzhayushchuyu sredu [P.2.1.10.1920-04. Guidelines for assessing public health risk from exposure to chemicals polluting the environment]. Moscow, 2004. $178 \mathrm{p}$.

7. Atiskova N.G., Shur P.Z., Romanenko K.V., Shlyapnikov D.M., Sharaeva A.A. Formirovanie spiskov prioritetnykh dlya garmonizatsii gigienicheskikh normativov soderzhaniya khimicheskikh veshchestv $\mathrm{v}$ atmosfernom vozdukhe [Creating lists of priorities for harmonization of hygienic standards for chemicals in the air]. Zdorov'e naseleniya $i$ sreda obitaniya, 2013, no. 11, pp. 7-9.

8. Canadian Environmental Quality Guidance, Canadian Council of Ministers of the Environment, 2007.

9. Concise International Chemical Assessment Document 12. Manganese And Its Compounds. WHO, 1999.

10. Davis C.D., Greger J.L. Longitudinal changes of manganese-dependent superoxide dismutase and other indices of manganese and iron status in women. Am. J. Clin.l Nutr., 1992, no. 55 , pp. 747-752.

11. Egyed M., Wood G.C. Risk assessment for combustion products of the gasoline additive MMT in Canada. Sci Total Environ, 1996, no. 189/190, pp. 11-20.

12. Kagamimori S., Makino T., Hiramaru Y., et al. Studies of effects on the respiratory organs of air pollution through dust consisting mainly of manganese. Nipon Koshu Eisei Zasshi [Japanese Journal of Public Health], 1973, no. 20, pp. 413-421.

13. The Report of the Scientific Steering Committee's Working Group on Harmonisation of Risk Assessment Procedures in the Scientific Committees advising the European Commission in the area of human and environmental health. First Report on the Harmonisation of Risk Assessment Procedures, Scientific Steering Committee, EU, Brussels, 26-27 October 2000, part 1. $173 \mathrm{p}$. 
Scientific and methodological approaches to risk analysis

14. Toxicological profile for manganese, U.S. Department of Health and Human Services, Agency for Toxic Substances and Disease Registry, September 2008. 